\title{
A Cross Sectional Study on Assessment of Health Profile of Policemen Serving at Ahmedabad City, Gujarat
}

\section{Sahil R Solanki ${ }^{1}$, Rujul P Shukla ${ }^{2}$}

${ }^{1}$ Resident, ${ }^{2}$ Assistant Professor, Department of Community Medicine, GCS Medical College, Ahmedabad, Gujarat, India Correspondence : Dr. Sahil R Solanki, Email: sahilsolanki777@yahoo.in

\begin{abstract}
:
Introduction : Policemen are one of the important cadres for positive pace of development of any nation. They can work optimally if, they are physically and mentally fit. Objective : To assess socio-demographic and health profile, determinants of ill health and their correlates with work profile of male policemen at Ahmedabad city. Method: Study was carried out at Police headquarters, Ahmedabad where policemen from all over district reported for work. Calculated sample size was 416. List of all policemen was obtained, participants were selected through simple random sampling, and personal interview was carried out at Police Headquarters of the city. Results : The mean age of study participants was $42.50 \pm 9.32$ years. In context to BMI, total75.3\% policemen were either overweight or obese. Policemen with tobacco addiction were $186(45 \%)$.Of total, $11.29 \%$ and $7.69 \%$ were hypertensive and diabetics respectively. Around threefourth $(74 \%)$ policemen complained of perceived stress. Conclusion: Two thirds of the total participants were overweight or obese. Factors like improper dietary habits, presence of disease, disturbed sleep and tobacco addictions among Policemen had a significant association with their work profile. Majority were under perceived stress and its consequences.
\end{abstract}

Key words: Addiction, Health profile, Obesity, Policemen, Sleep, Stress

\section{Introduction:}

It is increasingly recognized that a healthy workforce is a prerequisite for the success of economic and social policy. It is also a necessary condition for the achievement of sustainable development. One particular profession which takes care of the very social fabric that holds our nation together in peace is the police force. ${ }^{[1]}$

The main job of policemen is to maintain law and peace in society. ${ }^{[2]}$ Health is a way of functioning within one's environment. It is largely affected by work conditions so workplace environment plays an important role in man's total environment. ${ }^{[3]}$
Police work has been recognized as a dangerous occupation. They perform specialized work involving exposure to violence, which can affect their health directly or indirectly. ${ }^{[4]}$ They work under high-risk and uncontrolled environments, engage in extended driving, and often need to make on-the-spot decisions in complex and ambiguous situations. ${ }^{[5]}$

Good sleep quality and adequate sleep duration (i.e., 7 to 8 hours in a 24-hour period) are necessary for good health. ${ }^{[6]}$ The Policemen work routinely for 12 hours or more per day, sometimes which may extend to nonstop work for a couple of days at the police station. ${ }^{[7]}$ Policemen are one of the several risk

\begin{tabular}{|l|l|l|}
\hline Quick Response Code & Access this article online & How to cite this article: \\
\hline Solanki S, Shukla R, A Cross Sectional Study on \\
Assessment of Health Profile of Policemen Serving At \\
Ahmedabad City, Gujarat. Healthline. 2021;12(3): \\
Website : & www.healthlinejournal.org & \\
\cline { 2 - 3 } & DOI : & 10.51957/Healthline_240_2021 \\
\hline
\end{tabular}


groups for Non-Communicable Diseases(NCDs) as they have irregular diet, suffer from disturbed sleep pattern and have habits of Tobacco consumption. ${ }^{[8]}$

They face strong job demands besides being constantly under political and media scrutiny, many of those demands cannot be met adequately. There are many professional and legal strictures that circumscribe the policing response, which can lead to frustration and this overload with job demands causes strain and stress in individual police officers. ${ }^{[9]}$

The health of the policemen thus becomes very important as it could also affect the well being of the community he is serving. ${ }^{[1]}$ Due to paucity of literature on policemen of Ahmedabad City, present study was planned with objective to assess health profile of male police officer serving at Ahmedabad city.

\section{Objectives:}

1) To assess the overall health profile of male police officers serving at Ahmedabad City.

2) To assess various determinants of ill health factors among male police officers and correlate them statistically with their work and demographic profile.

\section{Method:}

A Cross Sectional study to assess the health profile of policemen was planned at Ahmedabad City, Gujarat. Permission of Institutional Ethics Committee and The Assistant Commissioner of Ahmedabad Police was obtained before initiating the study. From the appellate authority of police for Ahmedabad region, the permission was received to carry out the research among Police Sub Inspector (PSI) and subordinate official ranks i.e., Assistant Sub Inspector (ASI), Head Constable (HC) and Constable. Accordingly, the study was carried out amongst officers at Police Headquarters, Ahmedabad where around 3000 police officers of above mentioned rank reported daily who are serving at different police stations. Alist of all male police officers reporting at Ahmedabad Police Headquarters was obtained.
Based on findings of similar study carried out at Mumbai by Almale B. D. et al. ${ }^{[7]}$, p was taken as $48 \%$, $q$ as 100 -pwhich is $52 \%$, allowable error $E$ as $10 \%$ of $\mathrm{p}$ which is 4.8 , applying the formula: $\left[(1.96)^{2} \mathrm{pq} / \mathrm{E}^{2}\right]$ for sample size calculation, ${ }^{[10]}$ the final calculated sample size came to 416 .

From the list of all male police officers, the required numbers of participants were selected using simple random sampling method. Police officers who had served for less than 3 years were excluded from the study. In case a selected police official could not be contacted on day of visit, one more attempt was made to include participant in the study. After two consecutive efforts, the next immediate police official in the master list was selected.

The study duration was 3 months from September 2019 to November 2019. Data were collected by administering a self-designed prestructured questionnaire. The questionnaire included sociodemographic profile, personal history including addiction history, perceived stress related questions, history of preexisting disease and its treatment and details of duty hours. Measurements in examination included height, weight, waist circumference, hip circumference and blood pressure. Pilot testing of the questionnaire was done amongst $10 \%$ of sample size i.e., 42 participants before initiation of study.

Data entry was done in MS Excel and Analysis was done using IBM Statistical Package for Social Sciences for Windows version 20.0 Armonk, NY-IBM Corp. Data analysis included measurements of central tendency, measurements of dispersion, frequency and chi-square.

\section{Results:}

The mean age of study participants was $42.50 \pm 9.32$ years, mean height and weight being $170.63 \pm 0.5 \mathrm{~cm}$ and $74.23 \pm 10.5 \mathrm{~kg}$ respectively. Out of total policemen,331(79.6\%) had more than 10 years of work experience while $85(20.4 \%)$ had work experience of 3 to 10 years. 
Table 1 : Socio-Demographic Profile of study participants(n=416)

\begin{tabular}{|c|c|c|}
\hline Variables & Subclass & Frequency(\%) \\
\hline \multirow{4}{*}{$\begin{array}{c}\text { Age } \\
\text { (in completed years) }\end{array}$} & 21 to 30 & $36(8.7)$ \\
\hline & 31 to 40 & $149(35.8)$ \\
\hline & 41 to 50 & $121(29.1)$ \\
\hline & 51 to 58 & $110(26.4)$ \\
\hline \multirow[t]{4}{*}{ Education } & Secondary & $73(17.5)$ \\
\hline & Higher Secondary & $148(35.6)$ \\
\hline & Graduate & $186(44.7)$ \\
\hline & Post Graduate & $9(2.2)$ \\
\hline \multirow[t]{2}{*}{ Religion } & Hindu & $394(94.7)$ \\
\hline & Muslim & $22(5.3)$ \\
\hline \multirow[t]{2}{*}{ Type of Family } & Joint & $159(38.2)$ \\
\hline & Nuclear & $257(61.8)$ \\
\hline \multirow[t]{2}{*}{ Marital Status } & Single & $6(1.4)$ \\
\hline & Married & $410(98.6)$ \\
\hline \multirow{4}{*}{$\begin{array}{c}\text { Socioeconomic Status* } \\
\text { (Modified B.G. Prasad Classification) }\end{array}$} & Class 1 & $216(51.9)$ \\
\hline & Class 2 & $177(42.5)$ \\
\hline & Class 3 & $18(4.3)$ \\
\hline & Class 4 & $5(1.2)$ \\
\hline
\end{tabular}

*AICPI September 2019=322[11]

Among the policemen who were interviewed for the study, 247(59.4\%) were Constables, 87(20.9\%) were Head Constables,65(15.6\%) being ASI and 17(4.1\%) were PSIs.

Field Duty was performed by 343(82.5\%) participants, 54(13\%) had desk-work while $19(4.6 \%)$ policemen had both field and office duties to be accomplished during their postings. Frequency of change of shift was monthly for 395(94.9\%) policemen and daily for $21(5.1 \%)$.

Mean Waist and Hip circumferences of participant male policemen were $94.41 \pm 9.63 \mathrm{~cm}$ and $93.75 \pm 8.51 \mathrm{~cm}$ respectively. According to the commonly accepted standards ${ }^{[12]}$ almost half (206;
49.5\%) of the participants had Normal Waist Hip Ratio, while other 210(50.5\%) participants had Increased Waist Hip Ratio.

Mean Body Mass Index(BMI)of participants was $25.52 \pm 3.67 \mathrm{~kg} / \mathrm{m}^{2}$. As per Asian BMI Classification. ${ }^{[13]}, 80$ (20\%) participants were found to be overweight and 230 (55.3\%) were found to be under obese category. Mean Systolic blood pressure was $128.36 \pm 7.01 \mathrm{~mm} \mathrm{Hg}$ while mean Diastolic blood pressure was $80.62 \pm 3.66 \mathrm{~mm} \mathrm{Hg}$.

Almost half, 219(52.6\%) participants were on a Vegetarian diet, $177(42.5 \%)$ were Non-vegetarians and 20(4.9\%) were Eggetarians. Among the total study subjects, 224(53.8\%) had the habit of eating 
fast food during duty hours amongst which $143(63.8 \%)$ consumed fast food at least once a week.

Majority participants $373(89.7 \%)$ had 9 to 16 work hours per day. As shown in figure 1, disturbed sleep was found in 325 (78.2\%) policemen out of which $249(76.6 \%)$ had 1 to 10 days of night duty per month and $76(23.4 \%)$ had between 11 to 20 days of night duty per month.

Most of the policemen 410 (98.6\%) reported of having extra duty hours among which, extra duty hours ranging from 8 to 12 hours per week were reported by 371 (90.4\%) participants. Both

Figure 1: Prevalence of disturbed sleep and role of nightshift duty on same among study participants $(n=416)$

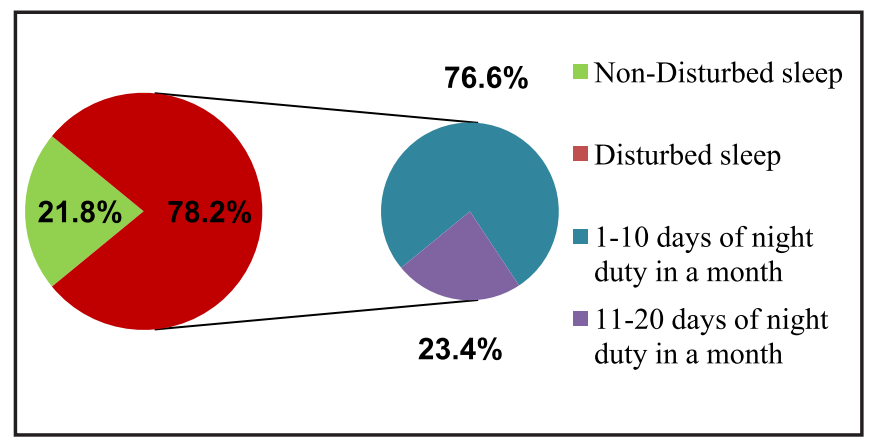

day/night shifts were performed by 379(91.1\%) policemen while $37(8.9 \%)$ had only day-time shift in the present routine.

Details about co morbidities suffered by participants and treatment taken currently are given in Table 2.

The most common disease found among policemen was hypertension (11.29\%) followed by diabetes(7.69\%).Gastrointestinal and Psychiatric diseases were the least common.

Various forms of tobacco addictions were present in 186 (44.8\%) policemen, out of which 31

Figure 2: Tobacco Addiction details among policemen $(n=416)$

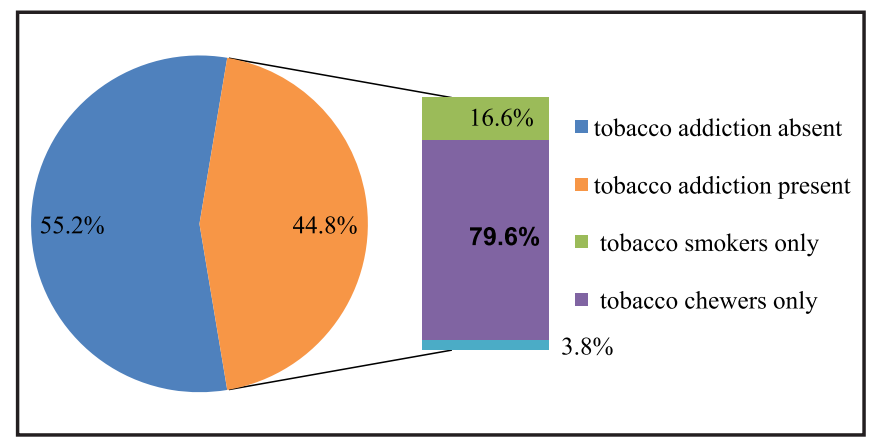

Table 2 : Disease profile and Treatment Status of study Participants $(n=125 ; 30 \%)$

\begin{tabular}{|c|c|c|}
\hline Disease* & $\begin{array}{c}\text { No. of Policemen with the } \\
\text { disease (\%) }\end{array}$ & $\begin{array}{c}\text { No. of Policemen } \\
\text { with Ongoing treatment for } \\
\text { disease present (\%) }\end{array}$ \\
\hline Hypertension & $47(11.29 \%)$ & $33(70.2 \%)$ \\
\hline Diabetes & $32(7.69 \%)$ & $24(75.0 \%)$ \\
\hline Musculoskeletal & $30(7.21 \%)$ & $13(43.3 \%)$ \\
\hline Skin disease and Hair problem & $13(3.12 \%)$ & $6(46.1 \%)$ \\
\hline Dental & $11(2.64 \%)$ & $1(9.0 \%)$ \\
\hline Respiratory & $7(1.68 \%)$ & $5(71.4 \%)$ \\
\hline Ophthalmic & $5(1.20 \%)$ & $1(20 \%)$ \\
\hline Gastrointestinal & $2(0.48 \%)$ & $2(100 \%)$ \\
\hline Psychiatric & $2(0.48 \%)$ & $1(50 \%)$ \\
\hline
\end{tabular}

*-Multiple Responses for disease were allowed 
Table 3 : Disease profile and Treatment Status of study Participants $(n=125 ; 30 \%)$

\begin{tabular}{|c|c|c|c|c|c|c|c|}
\hline \multirow{2}{*}{\multicolumn{2}{|c|}{$\begin{array}{l}\text { Perceived impact on } \\
\text { lifestyle variables }\end{array}$}} & \multicolumn{4}{|c|}{ Designation at the time of study } & \multirow{3}{*}{$\begin{array}{c}\text { Total } \\
186 \\
\end{array}$} & \multirow{4}{*}{$\begin{array}{c}\begin{array}{c}\text { Chi Square } \\
\text { Value } \\
\text { (P value) }\end{array} \\
\begin{array}{c}14.54 \\
(0.002)\end{array}\end{array}$} \\
\hline & & \multirow{2}{*}{$\begin{array}{c}\text { Constable } \\
99\end{array}$} & \multirow{2}{*}{$\begin{array}{c}\begin{array}{c}\text { Head } \\
\text { Constable }\end{array} \\
42 \\
\end{array}$} & \multirow{2}{*}{$\begin{array}{c}\text { ASI }^{*} \\
41 \\
\end{array}$} & \multirow{2}{*}{$\begin{array}{c}\text { PSI* }^{*} \\
4\end{array}$} & & \\
\hline Tobacco & Yes & & & & & & \\
\hline Addiction & No & 148 & 45 & 24 & 13 & 230 & \\
\hline Fast food & Yes & 162 & 32 & 25 & 5 & 224 & \\
\hline $\begin{array}{c}\text { consumption } \\
\text { habit }\end{array}$ & No & 85 & 55 & 40 & 12 & 192 & $\begin{array}{c}34.16 \\
(0.000)\end{array}$ \\
\hline & Yes & 153 & 49 & 43 & 10 & 255 & 1.64 \\
\hline Exercise & No & 94 & 38 & 22 & 7 & 161 & $(0.650)$ \\
\hline Diseased & Yes & 59 & 24 & 35 & 6 & 124 & 22.54 \\
\hline Condition & No & 188 & 63 & 30 & 11 & 292 & $(0.000)$ \\
\hline Work affects & Yes & 169 & 59 & 54 & 13 & 295 & 6.065 \\
\hline family life & No & 78 & 28 & 11 & 4 & 121 & $(0.108)$ \\
\hline Perceived & Yes & 90 & 37 & 35 & 10 & 247 & \\
\hline $\begin{array}{c}\text { Consequences } \\
\text { of Stress }\end{array}$ & No & 157 & 50 & 30 & 7 & 169 & $\begin{array}{c}6.63 \\
(0.084)\end{array}$ \\
\hline Disturbed & Yes & 201 & 59 & 50 & 15 & 325 & 8.01 \\
\hline Sleep & No & 46 & 28 & 15 & 2 & 91 & $(0.046)$ \\
\hline
\end{tabular}

\#Yates Correction $\quad * A S I=$ Assistant Sub Inspector $\quad *$ PSI = Police Sub Inspector

(16.6\%) had addiction for only tobacco smoking type, 148 (79.6\%) had addiction of only tobacco chewing type, while 7 (3.8\%) had both forms of tobacco addictions as shown in figure 2.0ut of total participants with tobacco addictions,105 (56\%) reported "stress" as a reason for intake of tobacco while 81 (44\%) reported observing and following habits of "peers" as their reason for intake of the same.

Table 3 shows statistical significant association between designation of police officers at the time of study and perceived impact on lifestyle variables such as tobacco addiction, fast food consumption habit, diseased condition and disturbed sleep. All the above mentioned risk factors were more commonly seen in lower ranking personnel (Constable and Head Constable).

Majority of policemen 335(80.5\%) did not play any sports, while 81(19.5\%) played sports like cricket, volleyball, football and kabaddi. Upto 60 minutes of sports activity was found in 24 (29.6\%) of participants while 57 (70.4\%) had more than 60 minutes of Sports activity.Those who played sports daily were 13 (3.1\%), 68(16.3\%) played sports as per their convenient days in a week.

During the last one year, 23 (5.5\%) policemen suffered from lower limb injury, 14 (3.4\%) had upper limb injuries, 13 (3.1\%) had head and neck injuries while $3(0.7 \%)$ had torso injuries as shown in figure 3. 406 (97.6\%) participants were living with their families while 10 (2.4\%) were living away from their home. Among total policemen in the study, 295 (70.9\%) said that their work did impact their family life while 121 (29.1\%) said their work did not impact family life.

403 (96.9\%) participants undertook medical checkups last year, out of which 368 (88.5\%) had undergone checkup once in previous year. 374 (89.9\%) of total participants stated Government requirement as a reason for medical checkup.Figure 4 shows exercise details of policemen, maximum police officers were doing other exercises like yoga and brisk-walking followed by running. Cycling was found to be the least common exercise among policemen. 
Figure 3: Distribution of Study Subjects according to anatomical site where injury was sustained during last one year( $n=53)$

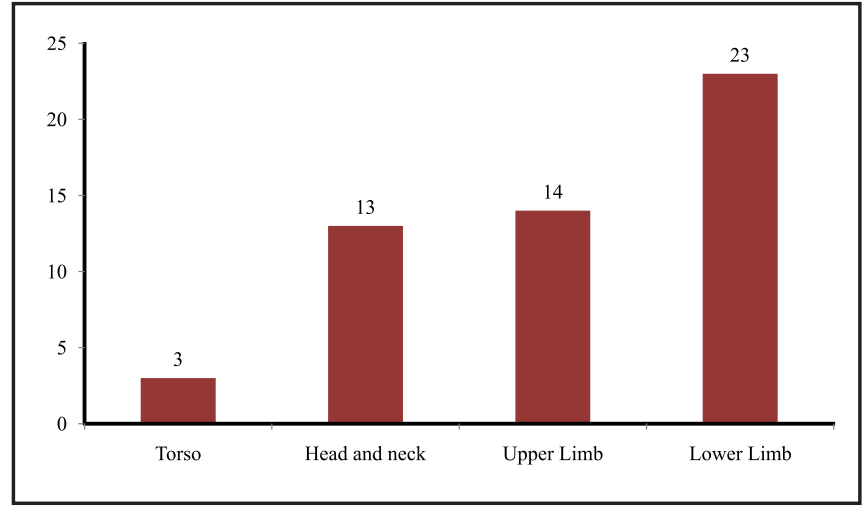

Figure 4 : Distribution of study participants according to the type of exercise preferred by them $(n=255)$

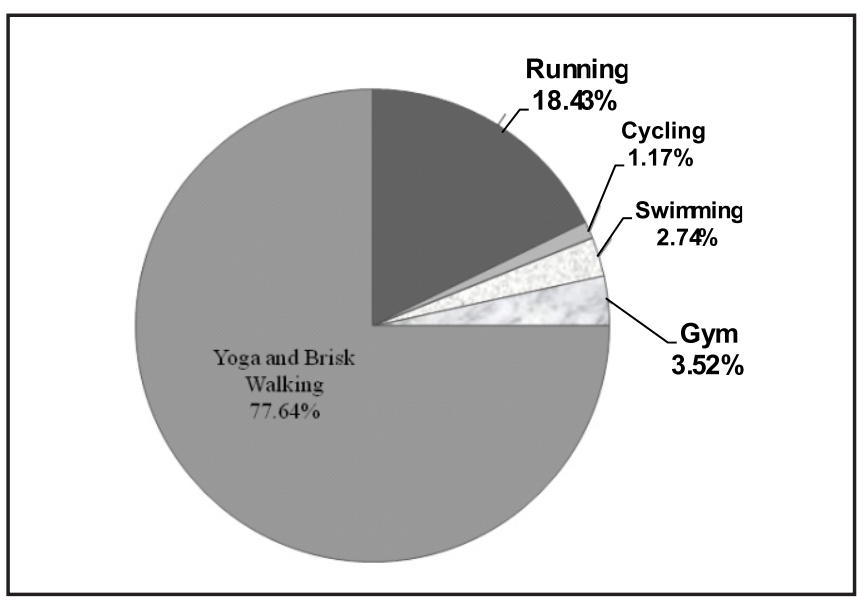

\section{Discussion:}

A total of 416 randomly selected male policemen were included as participant in present study. Maximum participants were in age group of 31 to 40 years $(35.8 \%)$. The mean age of study participants was $42.5 \pm 9.32$ years which is in accordance with Study on Policemen at Delhi [2] and Pondicherry. ${ }^{[8]}$ Almost half $(46.9 \%)$ of the participants had graduate or above education. In the present study, 44.7\% were graduates which is similar to the study at Delhi ${ }^{[2]}(47.3 \%)$ while another study at Mumbai ${ }^{[7]}$ showed 49\% participants with higher secondary education. Type of family as Nuclear family was found in most (61.8\%) participants. 98.6\% participants were married in the present study while $91 \%$ policemen were married in the study at Mumbai. ${ }^{[7]}$ Most participants (94.5\%) belonged to Class 1 and 2 of modified BJ Prasad Classification for Socioeconomic status.

Maximum policemen were of constabulary rank (59.4\%) in the present study while Delhi ${ }^{[2]}$ and Pondicherry ${ }^{[8]}$ Police Studies showed $79.3 \%$ and $67 \%$ constables respectively. Duty hours were 9-16 hours per day in most policemen $(89.7 \%)$ in present study while the same being 12-16 hours per day in 56\%

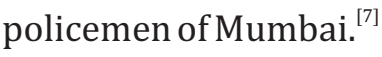

Mean Body Mass Index (BMI) in the present study was $25.52 \pm 3.67 \mathrm{~kg} / \mathrm{m}^{2}$ which is in line with Delhi ${ }^{[2]}$ Policemen showing mean BMI $25.6 \pm 3.6$ and Kolkata ${ }^{[14]}$ with mean BMI of $24.08 \pm 2.8$. Overweight (BMI >23) policemen were $20 \%$ and Obese (BMI $>25$ ) category were $55.3 \%$ in present study which is very similar to Pondicherry ${ }^{[8]}$ study showing overweight $25.3 \%$ and Obese $51.6 \%$.

Mean height and weight of policemen in the current study were $170.63 \pm 0.54 \mathrm{~cm}$ and $74.23 \pm$ $10.50 \mathrm{~kg}$ which were nearer to the findings of Kolkata $^{[14]}(172.77 \pm 4.93 \mathrm{~cm}, 71.94 \pm 9.37 \mathrm{~kg})$ and Delhi $^{[2]}(172.7 \pm 6.6 \mathrm{~cm}, 76.6 \pm 11.9 \mathrm{~kg})$ respectively.

As per a WHO report, ${ }^{[15]}$ a healthy waist hip ratio for men is 0.9 or less. Present study found higher mean waist hip ratio of $1.0 \pm 0.03$ similar to study in Delhi $(0.99 \pm 0.06)^{[2]}$

Tobacco addiction was found in 45\% policemen in present study which is much higher than $\operatorname{Delhi}^{[2]}(33.5 \%)$, Pondicherry ${ }^{[8]}$ (23\%) and even higher than Gujarat State Tobacco addiction (38.7\%) among adult men. ${ }^{[16]}$ Addiction was more common in participants having field duty compared to those having only office duty. Also, addiction was more common amongst lower cadre of participants. Possible reason may be their work in field duties.

More than quarter (30\%) participants suffered from one or more co-morbidities. Amongst that hypertension was most common. A meta-analysis in India ${ }^{[17]}$ showed the prevalence of hypertension in urban west India to be $35.8 \%$ in general population 
while present study showed much less prevalence of 11.29\% among policemen. Possible low prevalence in policemen may be due to their apparently healthy status at time of selection.

Mean systolic blood pressure was $128.36 \pm 7.0$ while a study among police personnel done at Chennai ${ }^{[18]}$ had mean systolic blood pressure $128.3 \pm$ 18.8 and Kolkata ${ }^{[14]}$ showed mean systolic blood pressure $130.81 \pm$ 13.43. Mean Diastolic blood pressure in present study was $80.62 \pm 3.66$ which is lower as compared to Chennai ${ }^{[18]}(85.5 \pm 12.5)$ and Kolkata $^{[14]}(82.08 \pm 7.06)$. Prevalence of Diabetes was $7.6 \%$ in police officers of present study which is lower than Delhi ${ }^{[2]}(12 \%)$, Kerala ${ }^{[1]}(12.5 \%)$, Mumbai ${ }^{[7]}(12.7 \%)$ and Pondicherry $(33.6 \%) .{ }^{[8]}$

Due to high workload almost three quarter of participants $(70.9 \%)$ informed that work stress affected their family life. $74.03 \%$ participants were under stress as per current study which is slightly higher than Pondicherry Police(69.5\%). ${ }^{[8]}$ And the work stress lead to various health related consequences like acidity, headache, peptic ulcer and insomnia.Most participants (61.3\%) had habit of regular exercising which is necessary to remain physically fit.

Statistical association was obtained between current designation and lifestyle habits like tobacco addiction and fast food consumption. These lifestyles were more common amongst lower cadre of policemen. Similarly, disturbed sleep and presence of co-morbidity was also more common amongst policemen of lower cadre. Possible reasons may be due to field work and stress to meet expectations of senior police officers.

\section{Conclusion:}

Present study showed high prevalence of Overweight and Obesity amongst male policemen of Ahmedabad city. Factors like Improper dietary habits, presence of disease, disturbed sleep and tobacco addictions amongst Policemen had a significant association with their work designation.
Majority suffered from perceived stress and their consequences.

\section{Recommendations:}

Periodic and more frequent Health checkups need to be carried out. A Holistic counseling approach which includes dietary counseling, stress management and de-addiction sessions are required. The Government needs to review health profile after certain specified fine interval and shall try to maintain a balanced work schedule for the protectors of the city.

\section{Declaration:}

Funding: Nil

Conflict of Interest: Nil

\section{References:}

1. Johns F, Kumar A, Alexander AV. Occupational Hazards Vs Morbidity Profile Among Police Force in Kerala. WwwImakmjCom. 2012;2(5):199-202.

2. Jitendra K. Meena, Rajesh Kumar GSM. Protect the Protector: Morbidity and Health Behavior among Police Personnel in National Capital Region of India. Indian J Occup Environ Med. 22(2).

3. Paudel L, Manandhar N, Joshi SK. Work-related musculoskeletal symptoms among Traffic police: A Review. Int J OccupSaf Heal. 2018;8(2):4-12.

4. Vijeth S. B., Ghouse Pasha VKSR. Prevalence of obesity and it's associated risk factors among policemen of Chitradurga district, Karnataka, India. Int J Adv Med. 5(5).

5. Fekedulegn, Desta PhD; Burchfiel, Cecil M. PhD; Charles, Luenda E. PhD; Hartley, Tara A. PhD; Andrew, Michael E. PhD; Violanti, John M. PhD Shift Work and Sleep Quality Among Urban Police Officers, Journal of Occupational and Environmental Medicine: March 2016 - Volume 58 - Issue 3 - p e66-e71

6. Charles LE, Slaven JE, Mnatsakanova A, Ma C, Violanti JM, Fekedulegn D, Andrew ME, Vila BJ, Burchfiel CM. Association of perceived stress with sleep duration and sleep quality in police officers. Int J EmergMent Health. 2011;13(4):229-41. PMID: 22900457 ; PMCID: PMC4681282.

7. Almale BD, Bansode-gokhe SS, Suryawanshi SR. Original Research Health Profile of Mumbai Police Personnel : a Cross Sectional Study. Indian J Forensic Community Med [Internet]. 2015;2(June):87-90. Available from: https://www. innovativepublication.com/admin/upload/IJFCM_2(2)_8790.pdf

8. Ramakrishnan J, Majgi SM, Premarajan KC, Lakshminarayanan S, Thangaraj S, Chinnakali P. High prevalence of cardiovascular risk factors among policemen in Puducherry, South India. J Cardiovasc Dis Res [Internet]. 2013;4(2):112-5. Available from: http://dx.doi.org/10.1016/j.jcdr.2013.05.002 
9. Almale BD, Vankudre AJ, Bansode-Gokhe SS, Pawar VK. An epidemiologic study of occupational stress factors in Mumbai police personnel. Indian J Occup Environ Med 2014;18:109-12

10. Mahajan's Methods in Biostatistics for Medical Students and Research Workers. Eighth edition revised and edited by Arun Bhadra Khanal. 2016.117-118p.

11. Consumer Price Index Numbers for Industrial Workers Base2016=100. Available at: http://labourbureau.gov.in/ LBO_Press_Release.htm

12. K.Park. Park's Textbook of Preventive and Social Medicine. 2019;25th Edition:429.

13. The Asia Pacific perspective: Redefining obesity and its treatment. Regional Office for the Western Pacific of the World Health Organization. World Health Organization, International Association for the Study of Obesity and International Obesity Task Force 2000. Available from: https://apps.who.int/iris/ bitstream/handle/10665/ 206936/0957708211_eng.pdf? sequence $=1 \&$ isAllowed $=y$

14. Sen A, Das M, Basu S, Datta G. Prevalence of hypertension and its associated risk factors among Kolkata- Prevalence of hypertension and its associated risk factors among Kolkatabased policemen : a sociophysiological study. 2015;(January).
15. Consultation WHOE. Waist Circumference and Waist-Hip Ratio Report of a WHO Expert Consultation. 2008;(December):8-11.

16. Global Adult Tobacco Survey GATS 2, Gujarat; 2016-17. Available from: https://tmc.gov.in/images/act/Gujarat GATS-2 Factsheet.pdf

17. Anchala R, Kannuri NK, Pant H, Khan H, Franco OH, Angelantonio E Di, et al. Hypertension in India: a systematic review and metaanalysis of prevalence, awareness, and control of hypertension. $2014 ; 32(6)$.

18. Tharkar S, Kumpatla S, Muthukumaran P, Viswanathan V. High prevalence of metabolic syndrome and cardiovascular risk among police personnel compared to general population in India. J Assoc Physicians India. 2008;56(NOV.):845-9. 